\title{
Eruption products of the 1883 eruption of Krakatau and their final settlement
}

\author{
Izumi Yokoyama
}

The Japan Academy, Ueno Park, Tokyo, Japan

\author{
Article history \\ Received March 19, 2014; accepted April 8, 2015. \\ Subject classification: \\ Krakatau caldera, Volume of the ejecta, Pyroclastic-fall and-flow, Caldera deposit, Magma reservoir.
}

\section{ABSTRACT}

Firstly the volume of pyroclastic ejecta during the 1883 eruption of Krakatau is re-examined. To revise the volume of flow deposits, the author basically follows Verbeek's observation while to estimate the fall deposits, as the last resort, the author assumes that volume ratios fall / flow are common to similar caldera eruptions, and the ratios determined by the caldera-forming eruptions of Novarupta and Pinatubo are applied to the Krakatau eruption. Verbeek's estimation of the total volume of ejecta, 12 $\mathrm{km}^{3}$ is revised to $19 \mathrm{~km}^{3}$. This is significantly different from the volume of disrupted volcano edifice, $8 \mathrm{~km}^{3}$. Such a result does not support the predecessors' hypothesis that calderas are formed by collapses of volcano edifices into magma reservoirs in replacement of the total ejecta. Through the discussion on the volume estimation of volcanic ejecta on and around Krakatau, the author recognizes that such estimation should be originally very difficult to attain enough accuracy. Much importance of "caldera deposits" to post-eruption settlements of the ejecta is emphasized. In relation to caldera formation, mechanical stability of a cavity in the crust is discussed. Lastly, upon the basis of subsurface structure, especially caldera deposits, a structural image of Krakatau caldera is presented.

\section{Introduction}

We have experienced caldera-forming eruptions four times since the 19th century, Tambora, Sumbawa in 1815, Krakatau, Sunda Straits in 1883, Novarupta, Alaska in 1912, and Pinatubo, Luzon in 1991. The Tambora eruption was exceptionally violent but not purposefully observed. Sigurdsson and Carey [1989] carried out field studies there and clarified that the eruption was a complex series of events for about 10 days developing its explosive phases. This eruption was rather exceptional in its sequences while the other three were observed more or less at scientific levels of those days and have been well studied until now. In the present paper, the 1883 eruption of Krakatau shall be discussed partly in the light of the last two caldera-forming eruptions although there exist many calderas formed in geological ages.
The 1883 Krakatau eruption has been studied by several distinguished researchers of the 20th century. Some of them have kept a conception that calderas were formed by collapses of volcano edifices into magma reservoirs in replacement of erupted magmatic material by reason of the paucity of lithic material around the calderas, and this conception presupposes equality of volume between discharged magmatic ejecta and disrupted volcano edifices. In order to verify the equality, we have to estimate the volume with reasonably high accuracy not in an order of magnitude: generally such estimation is impossible even now.

The difficulties in studies of the 1883 eruption of Krakatau are as follows:

(a) The eruption occurred in the midst of the sea and was accompanied with the dark of huge explosion clouds, and under no instrumental observations except a few accidental ones: a tide gauge and a pressure meter at Batavia located at about $160 \mathrm{~km}$ distance from the volcano. Consequently the sequence of this eruption or caldera formation has been not fully clarified.

(b) At that time, surveys of pyroclastic ejecta under the sea had been inexperienced. Around Krakatau Islands, the new eruption deposits suffered from effects of the Sunda Current: it was important to make a survey as soon as possible after the eruption to minimize post-depositional erosions. Verbeek [1885] may have preferred an immediate survey to an accurate one.

At present, an overall estimation of pyroclastic deposits in the sea area produced by the 1883 eruption is no more possible because of post-depositional erosions for more than 100 years, to say nothing of the land deposits. Thus, only Verbeek's observational data are uniquely available but have not been re-examined. We should recognize utility of the past estimation and promote the discussion on the 1883 eruption.

The topographic changes of Krakatau and its sur- 


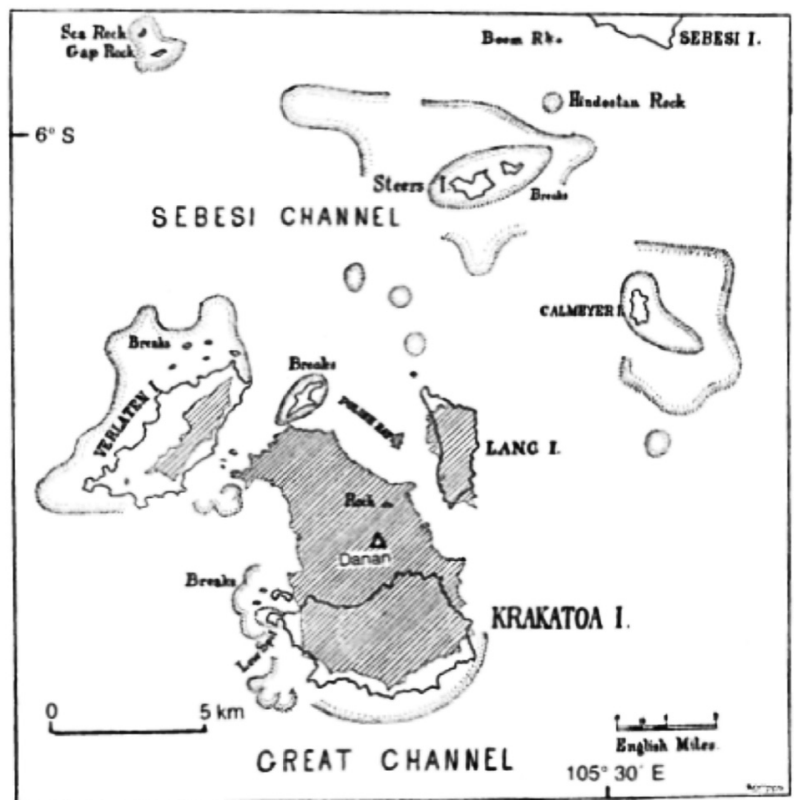

Figure 1. Chart of Krakatau and the surrounding islands, from the chart surveyed immediately after the eruption [from Judd 1888, fig. 11]. The shaded areas show the form of the islands drawn in the old chart. Dotted lines show sandbanks and lines of breakers. "Danan" is added by the present author.

rounding islands, surveyed immediately after the 1883 eruption by Judd [1888, fig. 11] are shown in Figure 1. These changes were caused by deposition of volcanic ejecta and explosive destructions. According to Judd, many of the topographic discrepancies at the southern limit of Krakatau were due to the imperfection of the old survey. This suggests difficulty in re-occupying the survey spots on the sea and in volume estimation of the submarine ejecta by using such charts.

After Verbeek [1885], several authors have repeated volume-estimation of pyroclastic ejecta from the 1883 eruption of Krakatau by their own manners. Their results shall be summarized in Section 3.3. About one month after the eruption, Verbeek started surveys of the volcanic ejecta in the sea by the techniques of those days. When we take the effects of post-depositional erosions in the Sunda Straits into consideration, we should appreciate the merit of Verbeek's early survey though his method was not necessarily complete.

\section{Volume estimation of pyroclastic-flow deposits of the 1883 eruption}

\subsection{Verbeek's volume estimation of pyroclastic ejecta}

Verbeek [1885] did not explicitly distinguish fall deposits from flow deposits. To estimate the total amount of ejecta around Krakatau Islands, he divided the area into two districts at and around the newly formed caldera; one is a circular area of $15 \mathrm{~km}$ in radius (Figure 2a) and the other is a wider area surrounding the former and extending toward the $\mathrm{N}$ and the $\mathrm{SW}$ to the maximum distance of about $1300 \mathrm{~km}$ (Figure 2b). In the former, Pieces I $\sim$ IV , and Rings a $\sim \mathbf{c}$, he compared the two bathymetric charts surveyed before and after the eruption, and in the latter, Rings $\mathbf{d}, \mathbf{e}, \mathbf{f}$, and $\mathbf{h}$,

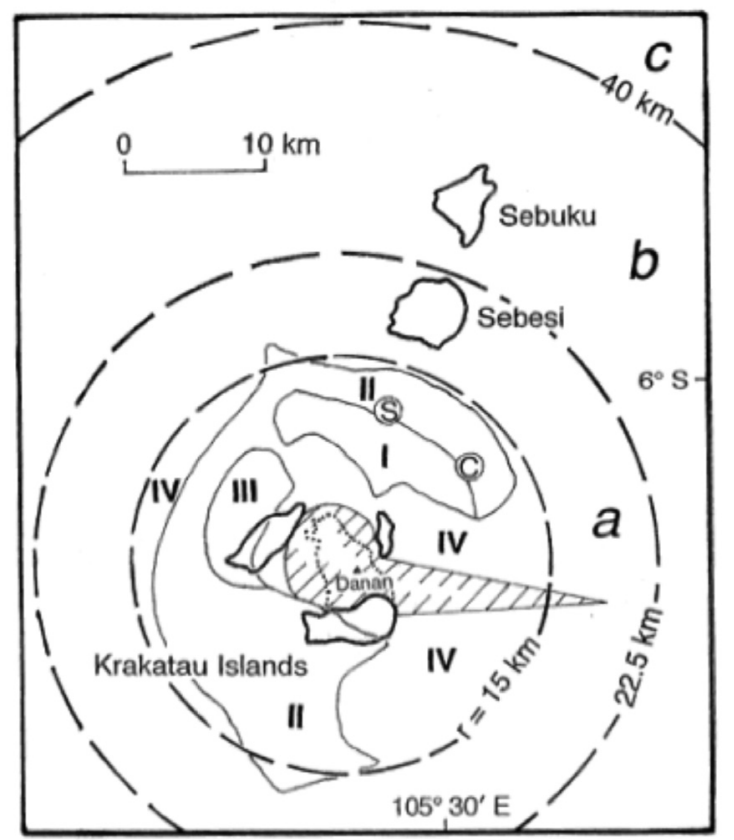

(a)

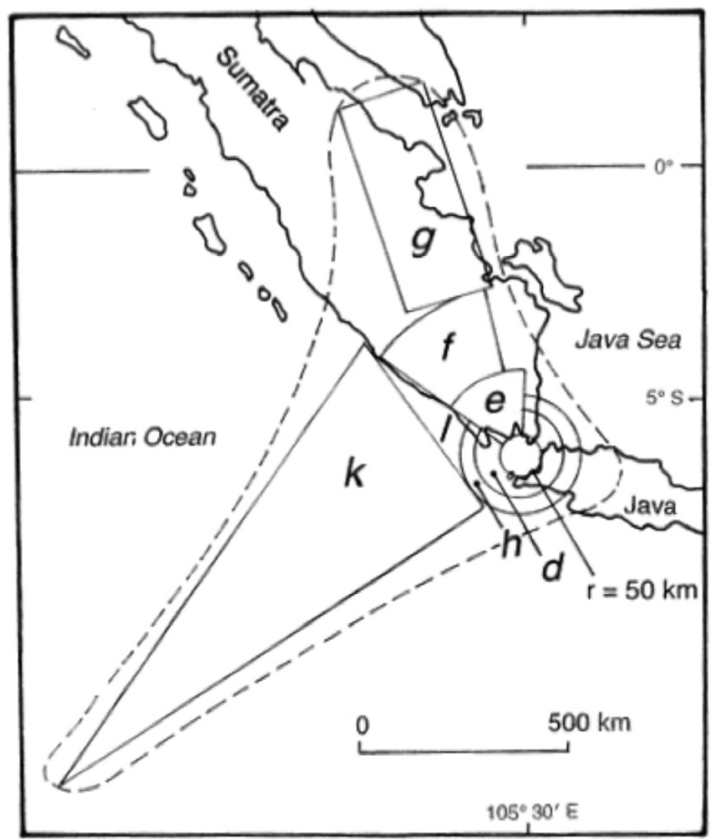

(b)

Figure 2. Division maps of Verbeek's survey of ejecta in and around the Sunda Straits. (a) Survey divisions of the inner area of Krakatau Islands: a simplified map of Verbeek's figure [1885, fig. 4]. Pieces I IV are within a circle of $15 \mathrm{~km}$ radius around Krakatau Islands, and Rings b, c and d successively continue to Ring a. (s) and (c) denote Steers and Calmeyer reefs, respectively. A hatched area is the caldera depression; Verbeek's method is not applicable there. (b) Survey divisions in the outer area of Krakatau Islands. The innermost circle $(\mathrm{r}=50 \mathrm{~km})$ includes Rings a, b, $\mathbf{c}$ and Pieces I $\sim$ IV shown in Figure 2a. 


\begin{tabular}{ccccccccccc} 
Division & $\mathbf{a}$ & $\mathbf{b}$ & $\mathbf{c}$ & $\mathbf{d}$ & $\mathbf{e}$ & $\mathbf{f}$ & $\mathbf{g}$ & $\mathbf{h}$ & $\mathbf{k}$ & $\mathbf{1}$ \\
\hline $\begin{array}{l}\text { Thickness } \\
\text { (in meter) }\end{array}$ & 1 & 0.3 & 0.2 & 0.02 & 0.05 & 0.01 & 0.001 & 0.005 & 0.005 & 0.005 \\
\hline
\end{tabular}

Table 1. Thickness of pyroclasic deposits in Division a $~ 1$ shown in Figures 2a and 2b after Verbeek [1885, pp. 133 and 134].

and Rectangle $\mathbf{g}$, Triangles $\mathbf{k}$ and $\mathbf{l}$, he roughly presumed thicknesses of the new deposits on the bases of the reports from the inhabitants and navigating ships in these areas.

He actually surveyed the depth changes within radial distance of $15 \mathrm{~km}$ from the center of the caldera (Pieces I IV). On the other hand, he did not survey in the area outside of Piece IV, but assigned presumed thickness for each Division as shown in Table 1.

In the table, the thickness of deposits discontinuously decreases ( 0.2 to $0.02 \mathrm{~m}$ ) between Divisions c and $\mathbf{d}(50 \mathrm{~km}$ from the center). Under such prearranged condition, the present author assumes that the deposits within a circular area of $50 \mathrm{~km}$ in radius (or Pieces I $\sim$ IV and Rings $\mathbf{a} \sim \mathbf{c}$ ) are mainly pyroclastic-flow deposits including a small quantity of pyroclastic-falls while in the outer area, almost all the deposits are pyroclastic-falls. Such distinction is one of the last resorts as far as we follow Verbeek's estimations, but may be not much unreasonable. In the fol-

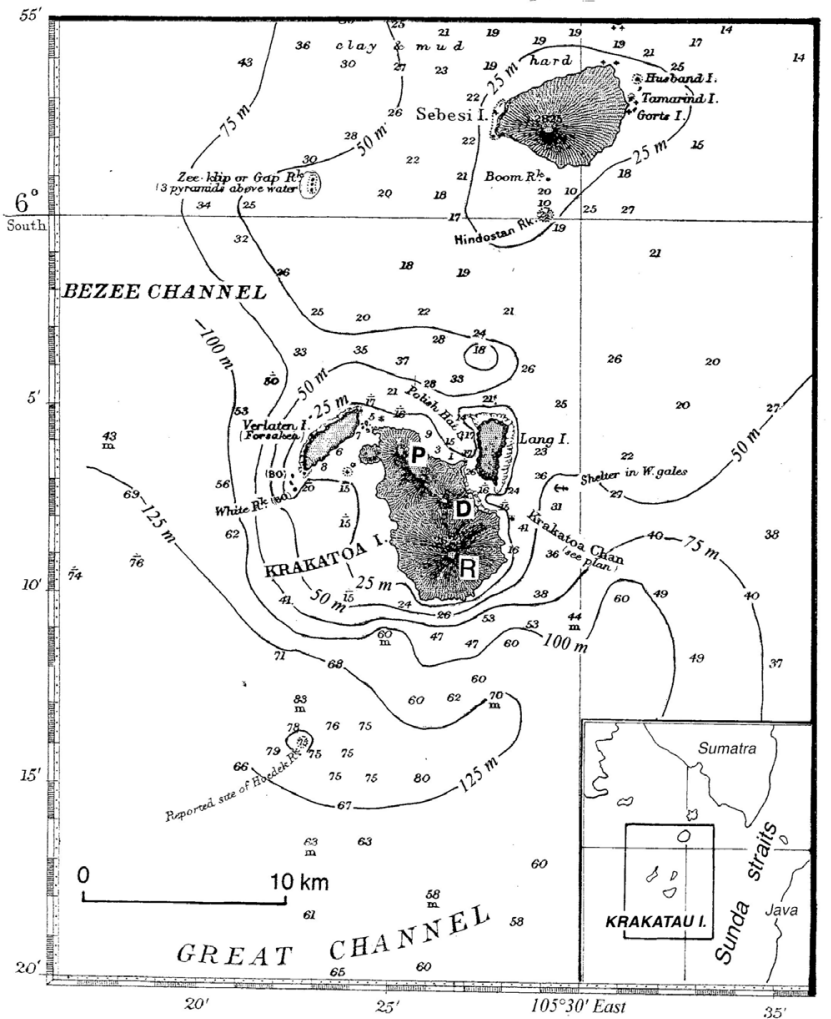

(a) lowing, Verbeek's results on pyroclastic-flow obtained only in a circular area of $15 \mathrm{~km}$ in radius (Pieces I $\sim$ IV) shall be re-examined, and the fall deposits in other Rings $(\mathbf{a} \sim \mathbf{c})$ remain the same as Verbeek's estimation. And the deposits in Divisions $(\mathbf{d} \sim \mathbf{l})$ are regarded as pyroclastic-falls, but the total volume of the fall deposits shall be re-estimated by analogical method with the other caldera-forming eruptions on land (Novarupta and Pinatubo) in Section 3.2.

\subsection{Revision of Verbeek's method to estimate pyroclas-} tic-flow deposits

Verbeek [1885] estimated volume of the ejecta by comparing the depths of the two charts of this area; namely, the Blommendal chart of 1874 and the Hydrograaf chart after the 1883 eruption as shown in Figures $3 \mathrm{a}$ and $3 \mathrm{~b}$, where the isobaths are added every $25 \mathrm{~m}$ by the present author. Verbeek presented the sea depths before and after the eruption together on a sheet as shown in Verbeek's Atlas [1885, fig. 4]. The present au-

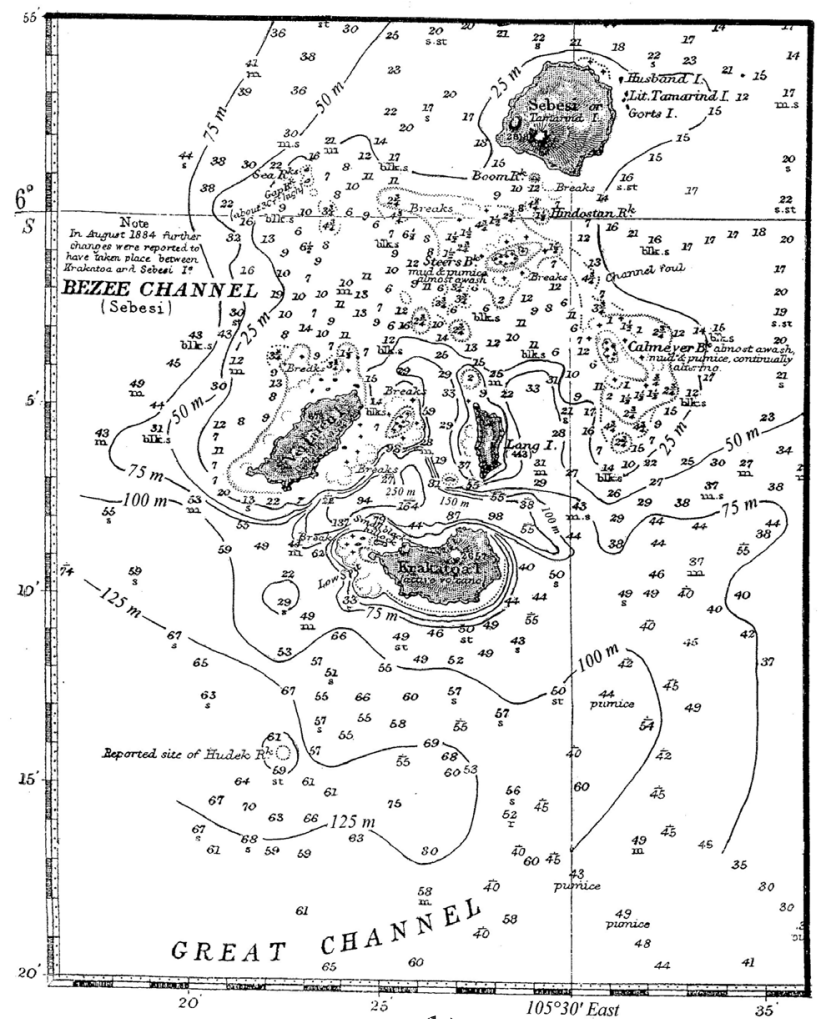

(b)

Figure 3. British Admiralty Charts surveyed before and after the 1883 eruption of Krakatau. In both the figures, the isobaths are added every $25 \mathrm{~m}$ by the present author. (a) Chart surveyed in 1854. Spot depths are in fathom ( 1 fathom $=1.83 \mathrm{~m}$ ). (s) and (c) denote the locations of Steers and Calmeyer reefs, respectively. P Perbuwatan, D Danan, $R$ Rakata. (b) Chart surveyed in 1886 . The central region collapsed to a depth of $250 \mathrm{~m}$ at the maximum. 


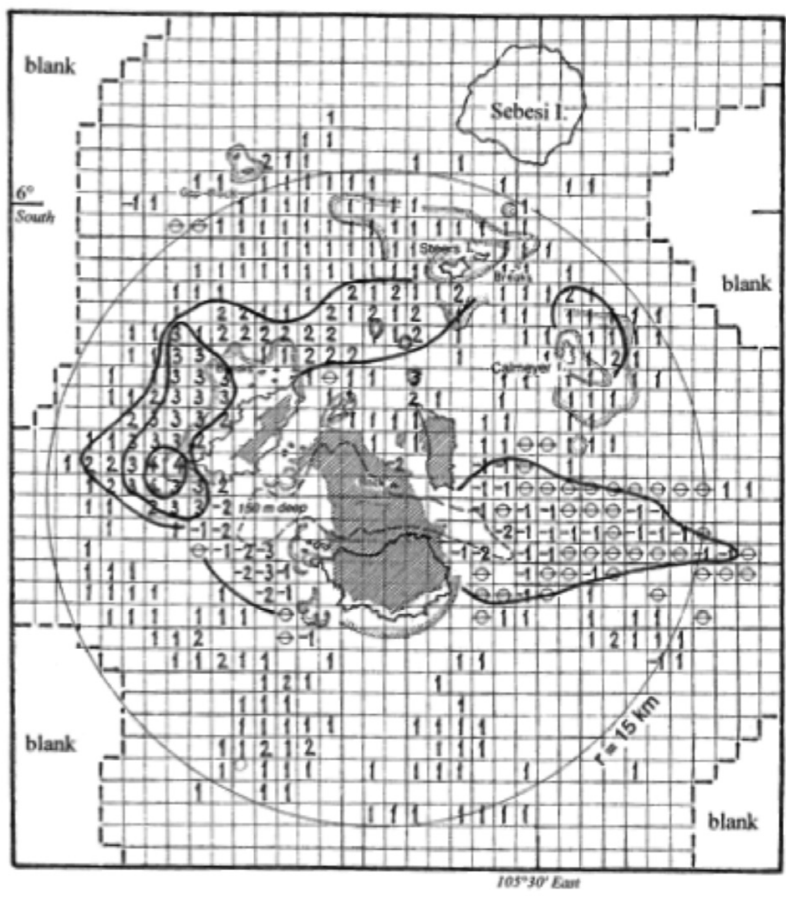

Figure 4. Distribution of thickness of volcanic ejecta, newly deduced from Figures 3a and 3b. Dotted lines show sandbanks and lines of breakers. The broken line in the central part contours an isobath of $150 \mathrm{~m}$ after the 1883 eruption. A circle of $15 \mathrm{~km}$ radius corresponds to that of Verbeek's figure (Figure 2a). A mesh is $1 \mathrm{~km}$ $\times 1 \mathrm{~km} . \ominus:<0$ (thin deposits); No numerals: $0 \sim 5 \mathrm{~m}$ (deposits of a few meter thick); 1: 6 15 m, roughly around $10 \mathrm{~m}$ thick; 2: 16 25 $\mathrm{m}$, roughly around $20 \mathrm{~m}$ thick $20 \mathrm{~m} ; 3: 26 \sim 35 \mathrm{~m}$, roughly around 30 $\mathrm{m}$ thick; 4: > $35 \mathrm{~m}$.

thor does not utilize this figure but compare both the depths in meshes of $1 \mathrm{~km}$ square as shown in Figure 4.

\subsubsection{Plumbings in the 19th century}

Verbeek [1885] measured thicknesses of the marine deposits of the Krakatau eruption by comparing the two bathymetric charts around Krakatau Islands, surveyed before and after the eruption; He relied on bathymetries by British and Dutch navies. Originally he had to directly measure thicknesses of the deposits, but such measurements require time, and hence he may have wished to obtain the result as early as possible to reduce the effects of post-depositional erosion by the current of the straits. This method is valid in case of thick deposits, several meters thick at least. For successful comparisons of two bathymetric charts surveyed at different periods, accurate re-locations of previous measuring points should be very desirable. In 1880s, re-locations were rather doubtful, especially in remote areas. We should take appropriate errors into consideration when we treat with Verbeek's results. The above comparison of bathymetric charts is not applicable to the area where the seabed was destructed by the eruption. It is concluded that his results contain some errors due to incomplete methods and inaccurate charts, particularly one surveyed before the eruption.
Verbeek [1885] did not describe any details of his bathymetries. Here, bathymettic methods in the 19th century shall be reviewed: echo-soundings were first adopted after 1920. In the 19th century, soundings at shallow sea were made usually by using a cable with a plumb of heavier than 7 pounds $(3.2 \mathrm{~kg})$. The accuracy of plumbings depends on verticality of plumb cables that is disturbed by the current thereabouts. Around Krakatau a few weeks after its eruption, the plumb of $3.2 \mathrm{~kg}$ weight may have penetrated the upper part of ejecta deposits, approximately $0.5 \mathrm{~m}$ in depth. By this method, it may have been rather difficult to measure the thickness of the deposits with high accuracy. At present, we can measure it directly by SCUBA core-samplings as used by Mandeville et al. [1996] or by seismic profilers and side-scan SONAR as used by Camus et al. [1991].

In those days, ships usually determined their positions by sextants, and its accuracy depended on visibility of landmarks around the ships. As shown in Figure 1, all Krakatau Islands drastically changed their shapes missing many remarkable topographies those were previously favourable targets of positioning. In sum, the overall errors in the comparison of the two surveys around Krakatau Islands consisted of those of soundings and those of positioning, and may have reached possibly more than a few meters. Here, we will follow Verbeek's method to re-estimate the volume of the 1883 ejecta, i.e. comparisons of the two charts, before and after the eruption. His data were published in his book of 1885 , and fortunately we can effectively refer various data of the 1883 eruption and the related problems to a book compiled by Simkin and Fiske [1983].

\subsection{Revised volume of the pyroclastic-flow deposits}

Verbeek may have obtained the differences between the two soundings on the charts. In Figure 2a, an area hatched by Verbeek [1885] was depressed by the eruption. This is the most important part in our discussion, but the resurveys could not be realized because the bottom topographies changed by the explosions. He grouped the central area of deposits into four Pieces $(\mathbf{I} \sim \mathbf{I V})$, assigning thicknesses of the deposits for each Piece as shown in Table 2.

In the present paper, to examine Verbeek's estimations, the author follows his method in principle and use similar two charts surveyed in 1854 and 1886, before and after the 1883 eruption, by British Admiralty and referred by Wharton [1888, plts. XXXII and XXXIII]. The charts are reproduced in Figures $3 \mathrm{a}$ and $3 \mathrm{~b}$ where the depths are in fathom $(1$ fathom $=1.83 \mathrm{~m}$ ) and the isobaths are added every $25 \mathrm{~m}$ by the present author. Strictly speaking, the two charts are not the same as Verbeek's ones. On this point, Judd [1888] 


\begin{tabular}{|c|c|c|c|}
\hline Unit & $\begin{array}{c}\text { Surface } \\
\left(\mathrm{km}^{2}\right)\end{array}$ & $\begin{array}{l}\text { Thickness } \\
(\mathrm{m})\end{array}$ & $\begin{array}{l}\text { Volume } \\
\left(\mathrm{km}^{3}\right)\end{array}$ \\
\hline Piece I & 54 & 20 & 1.08 \\
\hline \multirow{2}{*}{ Piece II } & 45 & $30 \rightarrow \underline{20}$ & $\underline{0.90}$ \\
\hline & 198 & $30 \rightarrow \underline{10}$ & $\underline{1.98}$ \\
\hline Piece III & 36 & $40 \rightarrow \underline{35}$ & $\underline{1.26}$ \\
\hline \multirow{3}{*}{ Piece IV } & 30 & $6 \rightarrow \underline{20}$ & $\underline{0.60}$ \\
\hline & 38 (caldera area) & $6 \rightarrow \underline{50}$ & $\underline{1.9}$ \\
\hline & 306 & $6 \rightarrow \underline{10}$ & $\underline{3.06}$ \\
\hline \multirow{2}{*}{ Total $\Sigma$} & \multirow{2}{*}{707} & & $\underline{10.8 \pm 3 \text { (bulk) }}$ \\
\hline & & & $\underline{8.7}(\mathrm{DRE})$ \\
\hline Ring $\mathbf{a}(\mathrm{r}=15 \sim 22.5 \mathrm{~km})$ & 883 & 1 & 0.883 \\
\hline Ring $\mathbf{b}(\mathrm{r}=22.5 \sim 40 \mathrm{~km})$ & 3434 & 0.3 & 1.030 \\
\hline $\operatorname{Ring} c(r=40 \sim 50 \mathrm{~km})$ & 2826 & 0.2 & 0.565 \\
\hline \multirow{2}{*}{ Total $\Sigma$} & \multirow{2}{*}{7143} & & $2.48 \pm 0.5$ (bulk) \\
\hline & & & 2.0 (DRE) \\
\hline Grand total $\Sigma \Sigma$ & 7850 & & 10.7 (DRE) \\
\hline
\end{tabular}

Table 2. Revised values of Verbeek's estimation in an area of $50 \mathrm{~km}$ in radius from the centre of the explosion. The deposits are mostly pyroclastic flows. Underlined values are revised ones. "caldera area" in Piece IV is the same as a hatched area in Figure 2a.

stated that the English chart was surveyed in 1854 and the Dutch one in 1874, but surveying officers of both the navies made additions and corrections to both the charts from time to time. Therefore, these two charts should be actually the same as Verbeek's ones.

The old chart has less numbers of plumbings and the depths in the two charts (Figures 3a and 3b) do not always correspond with each other. Several depths in the old chart were omitted from the new chart probably because of their uncertainty. It is difficult to draw the isobaths automatically. To improve scatterings and to get smooth distribution of the sea depths, the author newly contoured isobaths every $25 \mathrm{~m}$ (about 14 fathoms) by interpolations. Of course, these isobaths have some ambiguity, and drawings of every $10 \mathrm{~m}$ contours are impossible because of paucity and ambiguity of the measurements.

In order to estimate the depth changes objectively, both the charts (Figures $3 \mathrm{a}$ and $3 \mathrm{~b}$ ) are divided into meshes of $1 \mathrm{~km}$ square, and the median value in each mesh is determined as the average depth, and then the corresponding depths of the two charts are compared in each mesh. Thus, the changes in depth of the sea bottom due to the new deposits or the bottom displacements are represented in Figure 4 where mark - indicates a change smaller than $\pm 5 \mathrm{~m}$, numbers $1,2,3$, and 4 indicate changes of around 10,20,30, and $40 \mathrm{~m}$, respectively.

As mentioned above, around Krakatau Islands, the pyroclastic-flow deposits are distinguished from the pyroclastic-fall deposits at a boundary of $50 \mathrm{~km}$ radius from the center of the explosion. The flow-area is di- vided into 4 Pieces $\mathbf{I} \sim \mathbf{I V}$ and 3 Rings $\mathbf{a}, \mathbf{b}$ and $\mathbf{c}$ as shown in Figure 2a. Verbeek's estimations at each division are revised as follows:

Pieces I IV: the volume of deposits in the 4 Pieces is estimated on the base of Figure 4 and the results are tabulated in Table 2; Piece II is not uniform in thickness of the deposits, and divided into two by thickness. Piece IV includes the depression of the caldera and a triangular part (hatched part in Figure 2a), of which area is about $38 \mathrm{~km}^{2}$. We cannot apply Verbeek's method to this depression. Nevertheless Verbeek [1885] assigned $6 \mathrm{~m}$ as the thickness of the ejecta in all Piece IV. He did not pay any special attention to the depression that, in the present writer's opinion, should be the most important part of the Krakatau area after the eruption. We cannot exclude the possibility that many lithic fragments deposit there. Its bottom of $200 \mathrm{~m}$ deep covers an area of about $11.8 \mathrm{~km}^{2}$ in Figure 5. In Table 2, Verbeek divided Piece IV into three parts, all $6 \mathrm{~m}$ thick deposits. The area of the caldera depression (hatched area in Figure 2a) is $38 \mathrm{~km}^{2}$ and here the author assumes thickness of the caldera deposits to be $50 \mathrm{~m}$. This is not so overestimated considering that the maximum thickness of the deposits is $40 \mathrm{~m}$ in Figure 4. Thus Verbeek's estimates are revised and modified as shown in the last column of Table 2. The revised volume of Pieces I IV is converted into dense rock equivalent (DRE) as 10.8 $\mathrm{km}^{3} \times 2.1 / 2.6=8.7 \mathrm{~km}^{3}$ DRE.

In the table, Piece IV covers the caldera where there should be "caldera deposits" composed of fallbacks, i.e. juvenile ejecta and lithic fragments: it is im- 


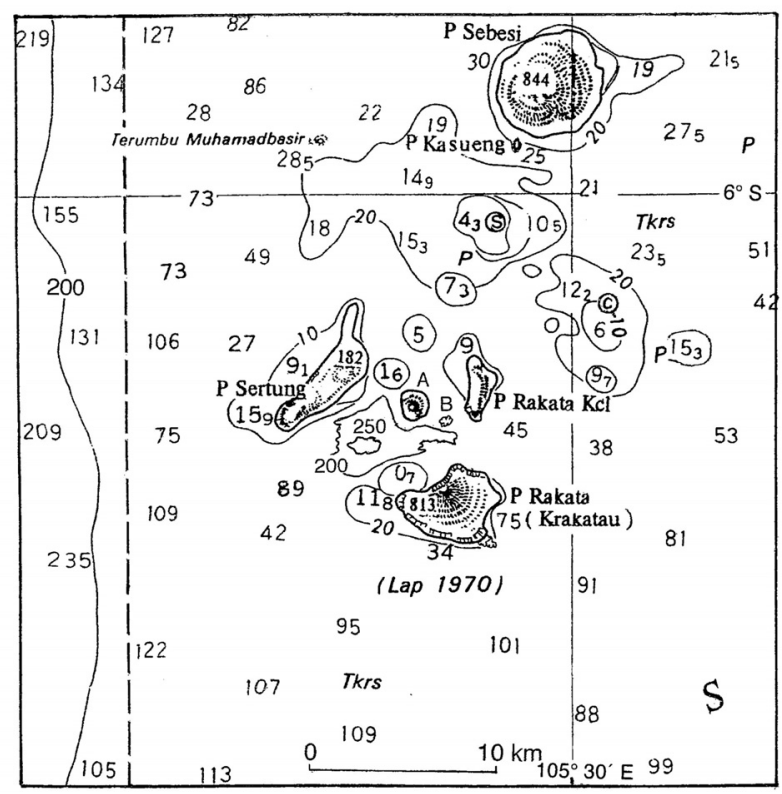

Figure 5. A part of Indonesian Chart around Krakatau Islands surveyed in 1970 by Kepala Dinas Hidro-Oseanografi. Spot depths are in meter. The isobaths of 200 and $250 \mathrm{~m}$ in the central part are drawn by the present author. Sertung and Rakata Kcl are another names of Verlaten and Lang, respectively. (S) and (c) near the crossing of the longitude and latitude lines denote Steers and Calmeyer reefs, respectively. A Anak Krakatau, $B$ Bootsmans Rots.

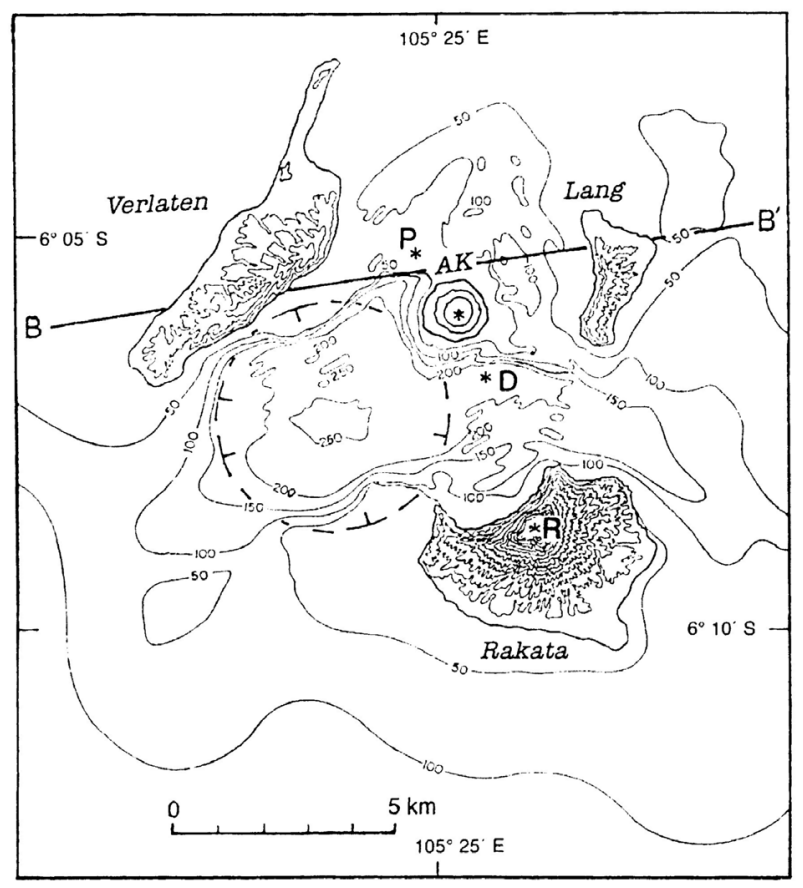

Figure 6. Topographic and bathymetric chart on and around Krakatau: a part of Indonesian Chart around Krakatau Islands surveyed in 1940 . The isobaths are drawn every $50 \mathrm{~m}$ and the contour intervals every $20 \mathrm{~m}$. AK Anak Krakatau, $R$ Rakata, $D$ Danan, $P$ Perbuwatan. A circle of broken line shows the assumed caldera rim.

possible for us to know their partitions at present. In the future, we shall get knowledge of the deposits by drillings at the spot. The caldera deposits shall be referred to in Section 4.1.

\subsubsection{Errors of Verbeek's volume estimation}

Pieces I III: Verbeek assigned thickness of the ejecta to 20,30 and $40 \mathrm{~m}$ for the three Pieces, respectively. In other words, he measured these depths with a unit of $10 \mathrm{~m}$ and the error is $\pm 5 \mathrm{~m}$. Thus, the error in estimation of the volume should be:

(Area of Pieces I $\sim$ III $) \times($ Error in thickness $)=($ Error in volume):

$(54+243+36) \mathrm{km}^{2} \times( \pm 5 \mathrm{~m})= \pm 1.7 \mathrm{~km}^{3} \approx \pm 2 \mathrm{~km}^{3}$.

Hence the total volume of Pieces I III is expressed as $\left(5.2 \mathrm{~km}^{3} \pm 2 \mathrm{~km}^{3}\right)$ in bulk. This error originates from only errors in measurement of the thickness, and varies with the locality.

2.3.2. Comments on the pyroclastic ejecta in the innermost region

(a) The central area among the three islands was depressed remarkably reaching deeper than $200 \mathrm{~m}$ b.s.l. To this caldera area, Verbeek's method is not applicable because the old depths were lost. Nevertheless, Verbeek [1885] assigned thickness $6 \mathrm{~m}$ to the all areas of Piece IV including the collapsed part, or the caldera depression in Figure 2a. The present author cannot understand the grounds for estimation of $6 \mathrm{~m}$ thick, and anew assigns thickness $50 \mathrm{~m}$ to the central area considering the maximum thickness of the deposits shown in Figure 4, as mentioned above. Verbeek did not take thought of caldera deposits.

(b) Danan has been assumed to be the main vent of the caldera forming explosions by some authors. However, the center of the existing depression is more probable as the explosion center because Danan was located outside the depression in Figure 6, and erupted as a parasite of pre-Krakatau volcano [Yokoyama 2014] before and during the 1883 climactic explosions.

(c) A large amount of ejecta was deposited roughly $40 \mathrm{~m}$ thick at the maximum off the NW coast of Verlaten (Sertung) Island in Figures 1 and 4. Stehn [1929] actually investigated the same deposition on the island. This means that the pyroclastic flows deposited on these areas after the large tsunami passed over there.

(d) Scarcely the sea depths changed at the S of Rakata Island within the limits of surveying errors. This means that the large explosions were directed mainly north- and northwestward.

(e) Reefs of Steers and Calmeyer: before the 1883 eruption, the two reefs were below the sea level as shown in Figure 3a, and after the eruption, they were observed above the sea between Lang and Sebesi Islands as in Figures 1, 3b and 4. These are located in Piece II as marked by letters (5) and (c) in Figures 2a 
and 5. The changes in depth around these reefs were not so much, or less than $25 \mathrm{~m}$. Originally these reefs were below the sea level because, on a chart (scale $1 / 500$ 000, 1970) shown in Figure 5, Steers and Calmeyer are $4.3 \mathrm{~m}$ and $6 \mathrm{~m}$ below the sea level, respectively. According to Judd [1888], the ejecta deposited temporarily on both the reefs during the eruption, had been completely washed away in a few months by the action of the sea waves. In Atlas of Verbeek [1885, fig. 4] or Simkin and Fiske [1983, p. 180, plt. 4], Steers stood 3 m above sea level and Calmeyer did $6.5 \mathrm{~m}$. Then, the ejecta are supposed to have deposited during the eruption on these reefs, $7.3 \mathrm{~m}$ and $12.5 \mathrm{~m}$ thick, respectively. These thicknesses are agreeable to those given in Figure 4. This means that the large tsunami on August 27 traversed this area before the pyroclastic ejecta deposited on these reefs. In other words, first the gigantic explosions occurred causing the large tsunami and strong airwaves, and later the pyroclastic-flows deposited on and around these reefs. Also this suggests importance of post-depositional erosions in the present discussion.

Rings $\mathbf{a}, \mathbf{b}$ and $\mathbf{c}$ (Figure 2a): we unwillingly cannot re-examine the data because Verbeek [1885] left the unique thickness of the deposits of $1,0.3$ and $0.2 \mathrm{~m}$, respectively. These thickness were not actually measured but probably may have been reported by the inhabitants on the islands. Eventually, adding the volume of Rings a, $\mathbf{b}$ and $\mathbf{c}\left(2.0 \mathrm{~km}^{3} \mathrm{DRE}\right)$ to the volume of Pieces I $\sim$ IV, the revised volume of the pyroclastic-flow deposits amounts to $10.7 \mathrm{~km}^{3} \mathrm{DRE}$ as shown in Table 2 . In the revised results, it is noticeable that about $80 \%$ of the flow-deposits remain within $15 \mathrm{~km}$ distance from the center of the eruptions.

2.3.3. Supplements to Verbeek's estimation of the flow deposits

(a) Volume of disrupted parts of Rakata Island: volume of disrupted volcanic edifices and sea bottom by 1883 eruption was not estimated by Verbeek, but is also important to draw a balance sheet between the volume of volcanic ejecta and disrupted volcanic edifices. Topographic maps of Rakata Island before the 1883 eruption were poor, and there were the three peaks on the island: Rakata (809 m), Danan (449 m) and Perbuwatan $(120 \mathrm{~m})$. By the eruption, the northern $2 / 3$ of the island disappeared and Rakata decreased its height to $803 \mathrm{~m}$. The volume of disrupted parts of Rakata Island above the sea level is calculated on the old and new topographic maps (Figures 3a and 6) as about $2.9 \mathrm{~km}^{3}$.

(b) Volume of topographic depression beneath the sea level: the 1883 eruption formed a depression between Rakata and Verlaten Islands in addition to disruption of 2/3 Rakata Island, and almost simultaneously these de- pressions were filled with mixture of the ejecta and sea water during the volcanic paroxysms, and after the 1883 eruption, a depression of funnel shape with maximum depth $250 \mathrm{~m}$ was left among the three islands (Figure 5). This is Krakatau caldera. The topographic depression under the sea level as of 1940 is shown in Figure 6 where probable caldera boundary is shown with a circle of broken line. Intensive explosions of Danan volcano may have caused eastward extension of the central depression. Volume of the topographic depression is estimated at $5.1 \mathrm{~km}^{3}$ on the charts of Figures $3 \mathrm{a}$ and 6 . This is "caldera depression". In the case of Krakatau, the volume of disrupted parts of Rakata Island above sea level (about $2.9 \mathrm{~km}^{3}$ ) is not included in the count.

(c) Deposits on the three islands in the central area: Verbeek [1885] did not pay particular attention to volume of the ejecta on the three islands. He assigned thickness of the ejecta on the three islands extrapolating the depth changes measured at the adjacent sea in Figure 2a where the average thickness of Pieces II, III and IV covering the three islands is about $20 \mathrm{~m}$ in Table 2. Considering that thickness of the ejecta on the three islands is about $20 \mathrm{~m}$ on the average based on Stehn's report [1929], we may assume the volume of deposits on the three islands as about $0.7 \mathrm{~km}^{3} \mathrm{DRE}$. This value was eventually included in Verbeek's calculation.

\section{Volume of pyroclastic-fall deposits of the $\mathbf{1 8 8 3}$ eruption}

\subsection{Verbeek's estimation of pyroclastic-fall deposits}

Originally volume estimation of fall deposits from volcanoes is problematic, especially at volcanoes in the midst of the sea. In the discussion of the 1883 eruption of Krakatau, we expect a large amount of pyroclastic-falls considering the anomalous "bigness" of the eruption [Simkin and Fiske 1983, p. 23] such as (1) a large volume of flow deposit, (2) energy coupled into the airwaves and tsunami, (3) the maximum eruptive column height: $50 \mathrm{~km}$, (4) long duration of climatic eruption: about 23 hours.

As already discussed in Section 2.1, according to Verbeek's data given in Table 1, the ejecta in the area from Ring $d$ to Triangle 1 , covering the sea and lands of $5 \times 10^{5} \mathrm{~km}^{2}$ in area (Figure $2 \mathrm{~b}$ ), are deemed as pyroclastic-falls. This area is the outside of $50 \mathrm{~km}$ radius from the center of the caldera. He assigned $0.001 \sim 0.02 \mathrm{~m}$ to thickness of the deposits at each division (Table 1) as far as $1400 \mathrm{~km}$ distance, and obtained the total amount of the ejecta in this area as $3.6 \mathrm{~km}^{3}$ bulk (Table 4). This is extremely rough estimation in comparison with that of flow deposits. His data based on the reports from the inhabitants and navigating ships at scattered and distant spots around the volcano. 
To convert the bulk volume to DRE volume, we need density of fall deposits. Sarna-Woicicki et al. [1981, fig. 339] obtained density distribution of the May 18, 1980, fall deposits from Mt. St. Helens along axis of downwind lobe: the density of air-fall deposits varies between $0.5 \sim 0.1 \times 10^{3} \mathrm{~kg} / \mathrm{m}^{3}$ with the distance from the volcano. Here, we adopt density $0.3 \times 10^{3} \mathrm{~kg} / \mathrm{m}^{3}$ for the fall deposits. Thus Verbeek's result of pyroclastic-fall deposits is modified to $0.4 \mathrm{~km}^{3} \mathrm{DRE}$ (Table 4) and the total volume of the flows and falls amounts to $12.2 \mathrm{~km}^{3} \mathrm{DRE}$.

3.2. Estimation of fall-deposits after the analogy of caldera-forming eruptions at Novarupta and Pinatubo volcanoes

When we try to revise the above Verbeek's estimation, it is clear that we can no more collect systematic data of the pyroclastic falls of the 1883 eruption. Here, to re-estimate the fall deposits, as the last resort, we assume that volume of pyroclastic-fall deposits is proportional to that of pyroclastic-flow deposits in the caldera forming eruptions provided that these eruptions would occur by similar mechanisms and processes. The volume of pyroclastic-fall deposits of the 1883 Krakatau eruption shall be speculated after the analogy with well-studied caldera-forming eruptions, Novarupta, Alaska in 1912 and Pinatubo, the Philippines in 1991. These two volcanoes are similar to Krakatau in explosivity or magnitude of eruptions and properties of magmas (andesite $\sim$ dacite $\sim$ rhyolite), and both the two calderas are filled with lithic-rich caldera deposits. Their eruptions were later than Krakatau, and have been studied much more with modern knowledge and methods, and furthermore both they are on land: the last is absolutely advantageous to estimate volume of the pyroclastic ejecta. There are many papers discussing their eruptions and transport processes of eruption deposits in detail. Some particulars of the three eruptions shall be comparatively discussed and are listed in Table 3.

Novarupta: Hildreth [1983] estimated volume of the ash-flow tuff at $11 \sim 15 \mathrm{~km}^{3}$ bulk, that is converted to about $8.2 \mathrm{~km}^{3}$ DRE, and Fierstein and Hildreth [1992, appx. 1] did that of the tephra falls at $6.8 \mathrm{~km}^{3}$ DRE. Hilddreth [1983] assumed $5 \%$ of the total ash falls and flows to be lithic material that derived from the former ground. This lithic material fills the caldera depression that was formed by explosive excavations. And further he assumed the caldera deposits to be about $1 \mathrm{~km}^{3}$ in volume, a half of the original ground. Thus, the original ground was approximated to an inverted cone (funnel-shape) of $2 \mathrm{~km}$ deep and $2 \mathrm{~km}$ in top diameter. In other words, about a half of the caldera deposits is reasonably presumed to be lithic fallbacks at Novarupta.

Pinatubo: the climatic eruption culminated with lithic-rich facies in the pyroclastic-flow deposits and resulted in formation of a caldera of $2.5 \mathrm{~km}$ in diameter. Scott et al. [1996] estimated volume of the pyroclasticflow deposits issued in various directions from the crater at $2.1 \sim 3.3 \mathrm{~km}^{3}$ DRE by the valley-cross-section method.

\begin{tabular}{|c|c|c|c|}
\hline Volcano & $\begin{array}{c}\text { Krakatau } \\
1883\end{array}$ & $\begin{array}{l}\text { Novarupta* } \\
\quad 1912\end{array}$ & $\begin{array}{l}\text { Pinatubo** } \\
1991\end{array}$ \\
\hline Rocks & andesite & ryolite, andesite, dacite & dacite \\
\hline $\begin{array}{l}\text { (a) Magma volume of pyroclastic- } \\
\text { flow deposit }\left(\mathrm{km}^{3} \mathrm{DRE}\right)\end{array}$ & 10.7 & 8.2 & $2.1 \sim 3.3$ \\
\hline $\begin{array}{l}\text { (b) Magma volume of pyroclastic- } \\
\text { fall deposit }\left(\mathrm{km}^{3} \mathrm{DRE}\right)\end{array}$ & $10.7 \times \underline{0.8}=8.6$ & 6.8 & $1.6 \sim 2.0$ \\
\hline (b) / (a): Fall-flow ratio & $* * *$ & $\underline{0.8}$ & $\underline{0.7}$ \\
\hline $\begin{array}{l}\text { Total volume of ejecta } \\
\left(\mathrm{km}^{3} \mathrm{DRE}\right)\end{array}$ & 19.3 & $\begin{array}{c}14 \sim 16 \\
\text { Mean } 15\end{array}$ & $\begin{array}{c}3.7 \sim 5.3 \\
\text { Mean } 4.5\end{array}$ \\
\hline $\begin{array}{l}\text { Volume of disrupted volcanic } \\
\text { edifices }\left(\mathrm{km}^{3}\right)\end{array}$ & 3 (a.s.l.) & 5 & $2.5+1.6=4.1$ incl. dilation \\
\hline $\begin{array}{l}\text { Volume of topog. depression } \\
\left(\mathrm{km}^{3}\right)\end{array}$ & 5 (b.s.l.) & 0.7 & 1.1 \\
\hline $\begin{array}{l}\text { Dia. of caldera surface } \\
(\mathrm{km})\end{array}$ & 5 & 2 & 2.5 \\
\hline $\begin{array}{l}\text { Duration of climatic eruption } \\
\text { (hour) }\end{array}$ & 23 & $11 \sim 16$ & $3 \sim 5$ \\
\hline $\begin{array}{l}\text { Max. column height } \\
(\mathrm{km})\end{array}$ & 50 & 26 & $34 \sim 40$ \\
\hline
\end{tabular}

Table 3. Comparison among the three caldera-forming eruptions. $(*)$ : after Hildreth [1983] and Fierstein and Hidreth [1992]; $(* *)$ : after Paladio-Melosantos et al. [1996] and Scott et al. [1996]; (***): (b) / (a) is assumed to be 0.8 . 
Paladio-Melosantos et al. [1996] distinguished tephra layers into A, B, C and D. C-layer is the most voluminous, $98 \%$ of the total volume, amounting to $1.6 \sim 2.0$ $\mathrm{km}^{3}$ DRE. Scott et al. [1996] also made a comparative discussion between Pinatubo and Novarupta eruptions, and independently assumed the caldera structure of Pinatubo to be funnel-shape of a large depth $(6 \sim 8 \mathrm{~km}$ b.s.l.) and full of lithic material: it is noticeable that the concept of "caldera deposits" was entertained in the discussions of both Novarupta and Pinatubo calderas.

Here we refer to the two large eruptions to check their relationships, if any, between volume of pyroclastic-flow deposits and pumice-fall deposits. If these are correlated, we may apply the correlation to the Krakatau eruption. In Table 3, the ratios of volume DRE of pyroclastic-fall to that of pyroclastic-flow (fall/flow ratio) in the eruptions of Novarupta and Pinatubo are roughly $0.7 \sim 0.8$. Such similar ratios may be not always accidental. If the ratios are approximately common to the eruptions of similar magmas and magnitudes, we may use the ratio to estimate volume of pumice-fall deposits of the third eruption of which volume of pyroclastic-flow is known. We apply the ratio 0.8 to the eruption of Krakatau. Then volume of the Krakatau pyroclastic-fall is approximately estimated at $8.6 \mathrm{~km}^{3}$ DRE that is comparable to that of Novarupta $\left(6.8 \mathrm{~km}^{3}\right)$. The fall deposits of Krakatau may have been distributed over the wider area than Novarupta considering the difference in their column heights. The total volume of the ejecta from Krakatau is revised to $(10.7+8.6) \mathrm{km}^{3}=$ $19.3 \mathrm{~km}^{3}$ DRE as shown in Table 4.

In the table, original Verbeek's estimation of the flow and fall deposits are converted to $11.8 \mathrm{~km}^{3}$ DRE and $0.4 \mathrm{~km}^{3} \mathrm{DRE}$, respectively. Assuming that the present re-estimation is correct, the difference is mainly due to underestimation of the pyroclastic-fall deposits. The present re-estimation of pyroclastic-fall deposits is approximate but may be more reasonable than Verbeek's estimate because the latter depended on scanty data. Verbeek [1885] commented on the errors of his estimation $\left(18.2 \mathrm{~km}^{3}\right.$ bulk in total) as "The figures everywhere used for thickness can be hardly be considered too large, but is most likely too small. The possible in- accuracy of this calculation, I think, is not more than 2 or at most $3 \mathrm{~km}^{3}$." Strictly speaking, we cannot argue the errors in Verbeek's estimation because we cannot evaluate the accuracy of the two charts used in his calculations. The present result, $19.3 \mathrm{~km}^{3}$ at the minimum, seems not so unreasonable comparing with $15 \mathrm{~km}^{3}$ of the 1912 Novarupta eruption in Table 3.

\subsection{Volume estimations of eruption products in the 1833} Krakatau eruption by various authors

After Verbeek, volume estimations of eruption products in the 1883 Krakatau eruption have been carried out, sometimes as a by-product of fundamental researches. Here, only the results in the volume estimation of pyroclastic-flows and -falls, and disrupted parts, by various authors shall be mentioned:

(1) Verbeek [1885] first carried out re-plumbing about one month after the 1883 eruption. This is a merit of his work if we consider post-depositional erosions. He did not discriminate between flows and falls, but in the present paper, these two are classified according to the distance from the eruption center (Table 1). Thus his estimation of the total volume of the ejecta amounts to $18.2 \mathrm{~km}^{3}$ bulk or $\mathbf{1 2 . 2} \mathbf{k m}^{3}$ DRE (Table 4).

(2) Archibald [1888] estimated volume of ash falls collecting reports of the dust falling on 8 ships traversing the Indian Ocean assuming its thickness to be 0.005 $\mathrm{m}$ and the area represented by these ships to be $2.8 \times 10^{6}$ $\mathrm{km}^{2}(1700 \mathrm{~km} \times 1700 \mathrm{~km}$; cf. Figure $2 \mathrm{~b})$. Then he got the total amount of ash fallout as $14.4 \mathrm{~km}^{3}$ bulk, or $\times 0.3 / 2.6=1.7 \mathbf{k m}^{3}$ DRE.

(3) Yokoyama [1981] determined volume of the total ejecta as $\mathbf{1 0}^{\mathbf{1}} \mathbf{~ k m}^{\mathbf{3}}$ in order of magnitude based on Verbeek's estimation $\left(18.2 \mathrm{~km}^{3}\right.$ bulk) and in consideration of its ambiguity. Also he deduced volume of "caldera deposit" as $9.3 \mathrm{~km}^{3}$ bulk from gravity anomalies, and later Yokoyama [2014] revised it to $13 \pm 3 \mathrm{~km}^{3}$ bulk by new knowledge on $\mathrm{Vp} / \mathrm{Vs}$ ratios [Jaxybulatov et al. 2011].

(4) Self and Rampino [1981] carried out field investigation on Krakatau Islands to correlate the eruption sequence with the stratigraphy of pyroclastic deposits. They evaluated the total volume of eruption deposits as $18 \sim 21 \mathrm{~km}^{3}$ bulk or $\mathbf{9} \sim \mathbf{1 0} \mathbf{k m}^{3}$ DRE, made up as fol-

\begin{tabular}{lcc|c} 
& \multicolumn{2}{|c|}{ Verbeek [1885] } & $\begin{array}{c}\text { This paper } \\
\text { DRE }\left(\mathrm{km}^{3}\right)\end{array}$ \\
\hline Pyroclastic-flow & Bullk & DRE $\left(\mathrm{km}^{3}\right)$ & Revised 10.7 \\
\hline Pyroclastic-fall & $(2.5+12.1)$ & $\times(2.1 / 2.6)=\mathbf{1 1 . 8}$ & *Newly \\
estimated 8.6
\end{tabular}

Table 4. Revised volume of the pyroclastic deposits on and around Krakatau Islands; $\left(^{*}\right)$ analogical estimation in Section 3.2. 
lows: $12 \mathrm{~km}^{3}$ bulk of pyroclastic deposits and $8.5 \mathrm{~km}^{3}$ bulk of ash fall deposits.

(5) Sigurdsson et al. [1991] collected SCUBA cores of the sediments in the area between Krakatau Islands and Sebesi Island, mainly around Steers and Calmeyer reefs, and newly constructed a bathymetric chart based on their 1990 survey, and a contour map of the changes in bathymetry. They followed Verbeek's manner and determined finally the total volume of the eruption products as $9.0 \mathrm{~km}^{3}$ DRE, and caldera depression as $8.9 \mathrm{~km}^{3}$ bulk.

(6) Mandeville et al. [1996] studied the stratigraphy of submarine pyroclastic deposits within a $15 \mathrm{~km}$ radius of the caldera collecting land-based and SCUBA cores, and estimated the volume of flow deposits as $12.4 \mathrm{~km}^{3}$ DRE and fall deposits as $\mathbf{2 . 3} \mathbf{~ k m}^{3}$ DRE: the total volume amounts to $14.7 \mathrm{~km}^{3}$ DRE.

(7) In the present paper, Verbeek's estimate of volume of the flow deposits is revised to $10.7 \mathbf{~ k m}^{3}$ DRE following his procedures. The volume of pyroclastic fall is assumed to be $80 \%$ of that of flow deposits on the analogy of the two caldera-forming eruptions: it is $8.6 \mathbf{~ k m}^{3}$ DRE. Finally the total amount of pyroclastic material is obtained as $19.3 \mathbf{~ k m}^{3}$ DRE. And the volume of disrupted volcano edifice is reckoned at $8 \mathrm{~km}^{3}$ bulk.

In a summary, the total volume of the ejecta from the 1883 Krakatau eruption calculated by various authors ranges over 9.0, 9.5, 12.2, 14.7 and $19.3 \mathrm{~km}^{3} \mathrm{DRE}$, as summarized above. The results are rather diverse because the above authors based on the different assumptions and the different data. After all, it may be concluded that the total volume of the Krakatau pyroclastic products including the flows and falls, widely ranges $9 \sim 19$ $\mathbf{k m}^{3}$ DRE, being roughly comparable to Novarupta and larger than Pinatubo, and that the volume of disrupted volcano edifice is roughly $8 \sim 9 \mathrm{~km}^{3}$ bulk according to some authors. Now we may say that we must be content with the volume estimation with accuracy of order of magnitude in the discussion of ejecta volume from the 1883 Krakatau eruption. In no distant future, we shall be able to estimate the volume of volcanic ejecta as mass flux at the level of volcano vents by remote sensing techniques in place of the present manner of searching the ejecta around volcanoes after eruptions.

\section{Subsurface structure of Krakatau caldera and set- tlement of the eruptive products}

\subsection{Caldera deposits of Krakatau caldera}

Generally caldera depression is defined as a vacant space formed by disruption of volcano edifices during violent explosions of pyroclastic ejecta. In the case of Krakatau caldera, the caldera depression was formed by disruption of $2 / 3$ parts of pre-existed Krakatau Is- land and excavation of the seabed to a depth of $250 \mathrm{~m}$. The present author [1981, 2014] discussed subsurface structure of the caldera by the gravity anomalies observed there, and assumed "caldera deposits" of low density immediately beneath the caldera depression, and estimated their volume at roughly $13 \mathrm{~km}^{3}$ bulk.

Van Bemmelen [1929, 1949] expressed his conception that disrupted volcano edifices collapsed into magma reservoir in replacement of the discharged material by magmatic eruptions. To accept this idea, the following two assumptions should be satisfied: (1) the volume of disrupted volcano edifice ("caldera depression") should be approximately equal to that of discharged magma, and (2) lithics of the volcano edifice scarcely remain at the surface around the caldera: in the following, we discuss the problems on Krakatau caldera.

Firstly, to verify assumption (1), both the volume should be similar in the exact numerals, not in the order of magnitude. The total volume of pyroclastic material of the Krakatau eruption is estimated at $19.3 \mathrm{~km}^{3}$ DRE in Table 4, and that of disrupted volcano edifice is reckoned as $(2.9+5.1)=8 \mathrm{~km}^{3}$ in Section 2.3: the ratio of (volume of ejecta) / (volume of disrupted volcanic edifice) is $(19.3 / 8)$. Here, we check the cases of Novarupta and Pinatubo calderas: in Table 3, the ratios are $(15 / 5.7)$ and (4.5/ 5.2), respectively. In short, Van Bemmelen's idea is narrowly valid in the Pinatubo eruption though clearly invalid in the Krakatau and the Novarupta eruptions. Hence we may conclude that the assumption proves not always to hold good.

Secondly, as for assumption (2), Verbeek [1885] reported that the ejecta mainly consisted of newly erupted magmatic material and fragments of the old volcano edifices, and that the latter volume amounted to $5 \%$ of the total. His estimation $5 \%$ may have been very rough admitting that the estimation method has not been established even now. Stehn [1929] observed a lithic part of $16 \mathrm{~m}$ thick of $40 \mathrm{~m}$ columnar section at the NW part of Lang Island. We can find other higher percentages in the recent literatures: $13 \%$ at the shore of Lang Island [Mandeville et al. 1996]. Simkin and Fiske [1983, p. 135, fig. 32] introduced the investigation report carried out by U.S. steamship Juniata around Krakatau Islands within 2 weeks of the catastrophic eruption: the crew prepared the first post-paroxysm map of Krakatau, dated September 10, 1883, in which we see several small islands formed of the fragmental deposits near Verlaten Island. Verbeek started his survey at the end of September and did not register such large amount of deposits. The delay of 2 weeks in the start of the surveys may be rather significant from the viewpoint of afterdepositional erosions. Hence, the present author doubts validity of $5 \%$ reported by Verbeek [1885]. 
We may assume the caldera deposits to be composed of juvenile pyroclastic ejecta and crushed precaldera rocks (lithic material): all these are fallbacks, and the latter may have been due to explosivity of the caldera-forming eruption. Admitting the volume equivalence between the caldera depression and the total erupted magmas, it is necessary to locate the magma reservoir and to explain the mechanism how the reservoir cavity was filled with the disrupted material. The validity of Van Bemmelen's assumptions should depend on the possibility of settlement of the eruption products into magma reservoirs.

4.2. Magma reservoir beneath Krakatau volcano and mechanical stability of a cavity in the earth crust

Williams [1941] supported Van Bemmelen's idea and established the 1883 Krakatau eruption as the typical example in collapses of a pre-existing volcanic edifice that was disrupted by large-scale eruption of silicic magma derived from a shallow magma reservoir.

"Shallow magma reservoirs" may be a rather difficult conception in the 21st century except "magma stops" between magma reservoirs and vents at some basaltic volcanoes. Beneath Krakatau caldera, searching for liquid zones, Harujono et al. [1989] detected several zones of strong attenuation of seismic S-waves and Jaxybulatov et al. [2011] determined the distribution of high $\mathrm{Vp} /$ Vs ratio of seismic waves; Yokoyama [2014] assumed a probable magma reservoir at a zone of about $10 \mathrm{~km}$ deep, characterized commonly by S-wave attenuation and high $\mathrm{Vp} / \mathrm{Vs}$ ratio as shown in Figure 7.

Here, mechanical stability of a magma reservoir with a cavity produced by magma ejection shall be examined: a cavity in the deep crust cannot exist against lithostatic pressure. If we assume compressive strength of the shallow crust to be $100 \mathrm{MPa}$, a cavity cannot exist at depths deeper than about $3 \mathrm{~km}$ in average. In other words, a magma reservoir at a depth deeper than $3 \mathrm{~km}$ should be crushed according as the magma is discharged from the reservoir. It is doubtful how the disrupted volcanic edifices can reach such magma reservoirs during formation of calderas.

In the present case, the cataclysm is assumed to start from a magma reservoir, not from a surface volcano. When a magma reservoir discharges magma partly or totally through a conduit leading to the volcano, the reservoir should be crushed partly or totally under crustal load when it is located at deeper than $3 \mathrm{~km}$. Here, for the sake of simplicity, we assume a spherical magma reservoir at a depth of $10 \mathrm{~km}$, and concentric crushing force $\mathrm{F}$ to act at the center of the reservoir. Timoshenko and Goodier [1970] discussed "Force at a point in an infinite solid", and their results are approximately appli-

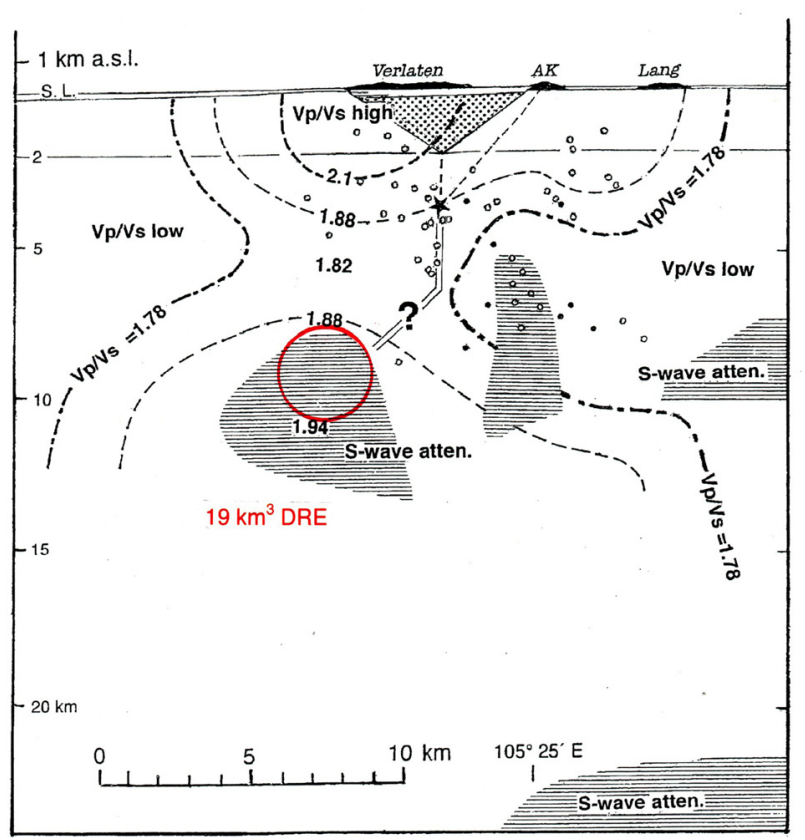

Figure 7. Assumptive caldera deposits and magma reservoir projected on a vertical plane along B-B' line in Figure 6. Dotted part schematically shows caldera deposits. Distribution of the S-wave attenuations (striped parts) was obtained by Harjono et al. [1989] and that of the Vp/Vs ratios by Jaxybulatov et al. [2011]. A colored circle on the assumed magma reservoir shows the total amount of the pyroclastic ejecta ( $\left.19 \mathrm{~km}^{3} \mathrm{DRE}\right)$ discharged by the 1883 eruption.

cable to the present problem. Beginning from Laplace's equation, they finally gave vertical stress $\sigma$ acting along the axis $r=0$ of cylindrical co-ordinates $(r, \theta, z)$ where the origin is the center of the cavity, as

$$
\sigma_{z, r=0}=\frac{F}{8 \pi(1-v)}\left\{(1-2 v+3) / z^{2}\right\}
$$

Assuming Poisson's ratio $v=0.25$, we get:

$$
\sigma_{z, r=0}=0.186 \mathrm{~F} / \mathrm{z}^{2}
$$

Qualitatively speaking, the reservoir should be crushed by lithostatic pressure according as the magma is discharged, and the effect of crushes of the reservoir (crushing force $F$ ) decreases rapidly in proportion to $z^{2}$. In other words, the crushing effect does not reach the surface when the reservoir is located at a sufficient depth.

If a magma reservoir were located at shallow depths, shallower than $5 \mathrm{~km}$, the crustal strength is much weaker than the deeper parts and cover rocks of the reservoir may be easily exploded. On Krakatau caldera, Yokoyama [2014] assumed depth of the caldera deposits to be about $2 \mathrm{~km}$ (Figure 7) and hence a shallow reservoir should be rather near to the caldera bottom. Anyway disrupted volcano edifices cannot settle at a magma reservoir in replacement of the discharged magma but may settle as caldera deposits. 
4.3. A model of Krakatau caldera viewed from its subsurface structure

Williams [1941] discussed general features of calderas and their origin but did not refer to their subsurface structure. Thus, he had no idea about caldera deposits. Yokoyama [1963] studied subsurface structure of some calderas and classified them into two: high-gravity- anomaly type and low-gravity-anomaly type. The gravity anomalies are due to density of the caldera deposits which have been verified by drillings at some calderas on land in Japan and Mexico [Yokoyama 2014].

At Krakatau caldera, Yokoyama [1981] analyzed low gravity anomalies observed on the islands and later Deplus et al. [1995] discussed the inner structure of the caldera analyzing gravity anomalies observed in a larger area around Krakatau Islands. Yokoyama [2014] interpreted the gravity anomalies to be due to mainly the caldera deposits of low density and estimated their volume at $13 \pm 3 \mathrm{~km}^{3}$. The Krakatau caldera depression $\left(5.1 \mathrm{~km}^{3}\right)$ is about $200 \mathrm{~m}$ deep b.s.l. and full of seawater. Beneath the caldera bottom, there exist caldera deposits that are composed of fallbacks of exploded materials (lithics and juveniles) and are soaked in seawater. The watery deposits are verified by anomalous values of $\mathrm{V}_{\mathrm{p}} / \mathrm{V}_{\mathrm{s}}$ ratio as high as 2.2 roughly around Krakatau caldera determined by Jaxybulatov et al. [2011]. On the other hand, Harjono et al. [1989] detected several seismic S-wave attenuating zones beneath the Krakatau islands. A vertical configuration of Krakatau caldera obtained by Yokoyama [2014] is reproduced in Figure 7 where the most probable zone of magma reservoir must be endowed with both the seismic-wave characters in common. This model has been achieved by contributions from several authors as mentioned above. The total volume of the ejecta discharged by the 1883 eruption (19.3 $\left.\mathrm{km}^{3} \mathrm{DRE}\right)$ is projected as a sphere on the assumed magma reservoir.

\section{Concluding remarks}

The estimation of volume of pyroclatic ejecta from the 1883 eruption of Krakatau originally carried out by Verbeek [1885] is revised in this paper principally based on his data. As a result, his estimation of the flow deposits proved to be acceptable while the fall deposits to be much underestimated. Its revision in the present paper is based on the assumption that the volume ratio, fall/flow is similar among caldera-forming eruptions, deduced from the 1912 eruption of Novarupta and the 1991 eruption of Pinatubo. As a result, the volume of pyroclastic fall is evaluated to be similar to that of the flow deposits.

Originally volume estimation of volcanic ejecta with reasonable accuracy is very difficult, especially on island volcanoes. In the case of the 1883 Krakatau eruption, we must be content to get results with accuracy of the order of magnitude, and so Van Bemmelen's assumption that the dense rock equivalent of the total ejecta derived from a caldera-forming eruption is the same as the volume of the resulting caldera depression, proved not necessarily to hold good. As for the final settlement of the disrupted volcanic materials, some papers have proposed that the materials settled in magma reservoirs in replacement of the discharged magma by reason of volumetric equality between both the materials. However, the equality is not always approved as discussed in the present paper and is not the necessary condition for caldera formations. On the other hand, the caldera deposits of Krakatau caldera are confirmed as well as some other calderas, and its magma reservoir is conjectured to be located at a depth of about $10 \mathrm{~km}$ from a geophysical standpoint. The paucity of lithic fragments among the Krakatau ejecta can be semi-quantitatively attributed to their settlement into the caldera deposits. The eruption products of the 1883 Krakatau eruption are discussed on their origin, volume and settlement on the base of the two examples of calderaforming eruptions that occurred under our eyes.

If the existence and the origin of "caldera deposits" are approved, we may define "caldera" of low-gravityanomaly type, from the viewpoint of subsurface structure as a large crater, such as larger than $2 \mathrm{~km}$ in diameter, with flat bottom, underlain by caldera deposits and accompanied with a large quantity of pyroclastic deposits around the volcano.

Acknowledgements. The above discussion is indebted to the data originally provided by Verbeek [1885]. The present author had a chance to read this priceless book at the Volcanological Survey of Indonesia, Bandung, and thanks Dr. S. Siswowidjoyo and Prof. A. Sudradjat for their kind cooperation. The author's knowledge on plumbing in old times owes to Dr. M. Tsuchide of the Hydrographic Department of Japan, to whom the author is grateful. Critical and helpful comments by anonymous referees are gratefully appreciated.

\section{References}

Archibald, E.D. (1888). General analysis of the connection between the unusual meteorological phenomena of 1883-6, and the eruptions of Krakatoa in May and August, 1883, In: G.J. Symons (ed.), The eruption of Krakatoa, and subsequent phenomena, 426-463.

Bemmelen, R.W., van (1929). Het Caldera probleem, De Mijningenieur, 10, 101-112.

Bemmelen, R.W., van (1949). Geology of Indonesia, Chapter 3: Volcanism, A. Active volcanism, The Hague: Govt. Printing Office, 188-224.

Camus, G., M. Gloaguen, A. Provost and P.M. Vincent (1991). Emplacement of a debris avalanche during the 1883 eruption of Krakatau (Sunda straits, In- 
donesia), XVII Pacific Sci. Cong. (Honolulu, May 27 - June 2, 1991), 3 pp. and 6 figs.

Deplus, C.S., S. Bonvalot, D. Dahrin, M. Diament, H. Harjono and J. Dubois (1995). Inner structure of the Krakatau volcanic complex (Indonesia) from gravity and bathymetry data, J. Volcanol. Geotherm. Res., 64, 23-52.

Fierstein, J., and W. Hildreth (1992). The Plinian eruptions of 1912 at Novarupta, Katmai National Park, Alaska, B. Volcanol., 54, 646-684.

Harjono, H., M. Diament, L. Nouaili and J. Dubois (1989). Detection of magma bodies beneath Krakatau volcano (Indonesia) from anomalous shear waves, J. Volcanol. Geotherm. Res., 39, 335-348.

Hildreth, W. (1983). The compositionally zoned eruption of 1912 in the Valley of Ten Thousand Smokes, Katmai National Park, Alaska, J. Volcanol. Geotherm. Res., 18, 1-56.

Jaxybulatov, K., I. Koulakov, M.I. Seht, K. Klinge, C. Reichert, B. Dahren and V.R. Troll (2011). Evidence for high fluid/melt content beneath Krakatau volcano (Indonesia) from local earthquake tomography, J. Volcanol. Geotherm. Res., 206, 96-105.

Judd, J.W. (1888). On the volcanic phenomena of the eruption, and distribution of the ejected materials, In: G.J. Symons (ed.), The eruption of Krakatoa, and subsequent phenomena, 1-56.

Mandeville, C.W., S. Carey and H. Sigurdosson (1996). Sedimentology of the Krakatau 1883 submarine pyroclastic deposits, B. Volcanol., 57, 512-529.

Paladio-Melosantos, M.L.O., R.U. Solidum, W.E. Scott, R.B. Quiambao, J.V. Umbal, K.S. Rodolfo, B.S. Tubianosa, P.J. Delosreyes, R.A. Alonso and H.B. Ruelo (1996). Tephra falls of the 1991 eruptions of Mount Pinatubo, In: C.G. Newhall and R.S. Punongbayan (eds.), Fire and mud, eruptions and lahars of Mount Pinatubo, Philippines, 513-535.

Sarna-Woicicki, A.M., S. Shipley, R.B. Waitt Jr., D. Dzurisin and S.H. Wood (1981). Areal distribution, thickness, mass, volume, and grain size of air-fall ash from the six major eruptions of 1980, In: The 1980 eruptions of Mount St. Helens, Washington, Geological Survey Professional Paper, 1250, 577-600.

Scott, W.E., R.P. Hoblitt, R.C. Torres, S. Self, M.M.L. Martinez and T. Nillos Jr. (1996). Pyroclastic flows of the June 15, 1991, climactic eruption of Mount Pinatubo, In: C.G. Newhall and R.S. Punongbayan (eds.), Fire and mud, eruptions and lahars of Mount Pinatubo, Philippines, 545-570.

Self, S., and M.R. Rampino (1981). The 1883 eruption of Krakatau, Nature, 294, 699-704.

Sigurdsson, H., and S. Carey (1989) Plinian and co-ignimbrite tephra fall from the 1815 eruption of Tamb- ora volcano, B. Volcanol., 51, 242-270.

Sigurdsson, H., S. Carey, C. Mandeville and S. Bronto (1991). Pyroclastic flows of the 1883 Krakatau eruption, EOS, 72, 377-392.

Simkin, T., and R.S. Fiskes (1983). Krakatau 1883: the volcanic eruption and its effects, Smithsonian Institution Press, Washington D.C., 464 pp.

Stehn, Ch.E. (1929). The geology and volcanism of the Krakatau group. Krakatau: Fourth Pacific Science Congress, Part I, 1-55.

Timoshenko, S.P., and J.N. Goodier (1970). Theory of elasticity, McGraw-Hill Book Co., New York, 567 pp.

Verbeek, R.D.M. (1885). Krakatau, Landsrukkerij, Batavia, 546 pp.

Wharton, W.J.L. (1888). On the seismic sea waves caused by the eruption of Krakatoa, August 26th and 27th, 1883, In: G.J. Symons (ed.), The eruption of Krakatoa, and subsequent phenomena, 89-150.

Williams, H. (1941). Calderas and their origin, Univ. California Pub., Bulletin of the Department of Geological Sciences, 25, University of California Press, 239-346.

Yokoyama, I. (1963). Structure of calderas and gravity anomaly, B. Volcanol., 26, 67-72.

Yokoyama, I. (1981). A geophysical interpretation of the 1883 Krakatau eruption, J. Volcanol. Geotherm. Res., 9, 359-378.

Yokoyama, I. (2014). Krakatau caldera deposits: revisited and verification by geophysical means, Annals of Geophysics, 57 (5), S0541.

Corresponding author: Izumi Yokoyama, The Japan Academy, Ueno Park, Tokyo, Japan; email: iyokoyama@joy.ocn.ne.jp.

(C) 2015 by the Istituto Nazionale di Geofisica e Vulcanologia. All rights reserved. 